\title{
EGFR NP_005219.2:p.R108K
}

National Cancer Institute

\section{Source}

National Cancer Institute. EGFR NP 005219.2:p.R108K. NCI Thesaurus. Code C159422.

A change in the amino acid residue at position 108 in the epidermal growth factor receptor protein where arginine has been replaced by lysine. 